\title{
Differences in Tumor Necrosis Factor (TNF) $\alpha$ and TNF Receptor-1-Mediated Intracellular Signaling Factors in Normal, Inflamed and Scar-Formed Horse Tendons
}

\author{
Yoshinao HOSAKA $^{1)}$, Rikio KIRISAWA ${ }^{2)}$, Hiromi UEDA ${ }^{1)}$, Mamoru YAMAGUCHI ${ }^{3)}$ and Kazushige TAKEHANA ${ }^{1)}$ \\ ${ }^{1)}$ Departments of Veterinary Anatomy, ${ }^{2)}$ Veterinary Microbiology, School of Veterinary Medicine, Rakuno Gakuen University, Ebetsu \\ 069-8501 Japan and ${ }^{3)}$ Department of Veterinary Biosciences, School of Veterinary Medicine, The Ohio State University, Columbus, Ohio \\ 43210, U.S.A.
}

(Received 1 February 2005/Accepted 2 June 2005)

ABSTRACT. Tumor necrosis factor (TNF) receptors (TNF-R)-mediated cell survival or apoptosis has been demonstrated in many cells, but little is known about survival or apoptotic signals via TNF-R1 in tendinocytes. In this study, we focused on four signaling factors, TNF $\alpha$, TNF-R1, TNFR-associated factor2 (TRAF2) and caspase-3, in order to elucidate the signaling events in tendinocytes. Samples were obtained from normal, inflamed and scar-formed equine superficial digital flexor tendons. To detect these signaling factors, samples were subjected to immunohistochemistry and Western blot analysis, and some samples were also subjected to reverse transcription-polymerase chain reaction (RT-PCR), PCR-Southern blot analysis and in situ hybridization to detect the expression of TNF $\alpha$ mRNA. Distribution of the four factors differed depending on the tendon condition, normal, inflamed or scar-formed. In the normal tendon, large amounts of TRAF2 were found in tendinocytes, but the amounts of TNF-R1 were small. TNF $\alpha$ mRNA was expressed most highly in the inflamed tendon. TNF-R1, which was only faintly detected in the normal tendon, was detected at a high level in the inflamed tendon, and the amounts of TRAF2 and caspase-3 also increased. Activated caspase-3 was only detected in the inflamed tendon. TNF $\alpha$ mRNA was also expressed in the scar-formed tendon, though it showed weak signals, and the expression levels of TNF-R1, TRAF2 and caspase-3 proteins were very low. Two distinct intracellular signaling pathways of TNF $\alpha$, which lead to cell survival and apoptosis, might be present in tendinocytes mediated through TNF-R1. These results, which reflect the dynamism of TNF $\alpha$, provide important clues for means to prevent tendinopathy.

KEY WORDS: caspase-3, equine tendon, tumor necrosis factor $\alpha(\mathrm{TNF} \alpha)$, tumor necrosis factor-receptor 1 (TNFR1), TNF receptor-associated factor-2 (TRAF2).

J. Vet. Med. Sci. 67(10): 985-991, 2005

Tumor necrosis factor (TNF) $\alpha$, a pleiotropic cytokine, can lead to survival and proliferation of cells and cell death (apoptosis) by binding to TNF receptors, TNF-R1 and TNFR2 [13, 16, 27, 33]. Such pleiotropic effects are mediated by two distinct TNF receptors, although TNF-induced cell death is mediated only by TNF-R $1[25,26]$. In response to TNF $\alpha$, TNF-R1 is trimerized and recruits an adaptor molecule, TNF receptor-associated death domain (TRADD) [8, 25]. In the intracellular apoptotic-signaling pathway, TRADD interacts with another protein, Fas-associated death domain (FADD) [2, 7], which then recruits and activates procaspase- 8 . The activated caspase- 8 in turn activates effector caspases, such as caspase- 3 or -7 , resulting in apoptosis $[10,20]$. On the other hand, TRADD, which is mediated by TNF-R1, also interacts with other binding protein, TNF receptor-associated factor-2 (TRAF2), of which implicated in nuclear factor (NF)- $\kappa \mathrm{B}[24,25]$. NF- $\kappa \mathrm{B}$ is deeply involved in cell proliferation and prevention of TNF $\alpha$ induced apoptosis $[1,3,14,30,32]$. Thus, TNF $\alpha$ has the potential to lead to cell survival or apoptosis by binding to TNF-R1.

We have recently reported that TNF $\alpha$ is distributed and expressed in tendinocytes in an inflammatory condition and that there is excessive apoptosis and proliferation of tendinocytes in an inflamed superficial digital flexor tendon
(SDFT) of the horse [4-6]. As mentioned above, TNF $\alpha$ is known to play an important role in an inflamed tendon, but it has not been determined whether TNF $\alpha$ acts as an antiapoptosis factor or an apoptotic factor in equine tendinocytes. Additionally, the signaling events in tendinocytes mediated by TNF-R1 remain unknown.

Elucidation of the role of TNFa in the tendon and of TNF-R1-mediated intracellular signaling events would make it possible to control the cell number and the smooth healing of tendon. It would also provide important clues for means to prevent the occurrence of tendonitis and progress of degeneration of tendon tissue. In this study, to elucidate the signaling events in the tendon, we focused on four signaling factors, TNF $\alpha$, TNF-R1, TRAF2 and caspase-3, and investigated the differences in distribution and expression of these factors in normal, inflamed and scar-formed tendons.

\section{MATERIALS AND METHODS}

Animals and tissue specimens: Sixteen specimens of SDFT, 6 normal tendons, 6 inflamed tendons and 4 scarformed tendons, were obtained from 13 Thoroughbred horses. Two of the inflamed tendon specimens were obtained from a single horse, one inflamed and one normal specimens were also obtained from another single horse, 
and one scar-formed and one normal specimens were obtained from another single horse. The average $( \pm$ SD) age of the horses was $4.6 \pm 2.1$ years (range, $1-7$ years), and there were 5 males and 8 females. All horses were housed at Rakuno Gakuen University for teaching and research purposes until subjecting to euthanasia (see below). This study was performed in accordance with the Guidelines for Animal Experimentation of Rakuno Gakuen University, Japan. Tendons that showed no abnormal postmortem had not been associated with clinical tendonitis during life. Two horses with inflamed tendons had shown clinical tendonitis (lameness and pain following injury, with confirmation by ultrasonography). Other animals had shown no clinical signs, but tendonitis was discovered postmortem. After sedation with an injection of medetomidine hydrochloride $(16 \mathrm{mg} /$ $\mathrm{kg}$, intramuscularly) and anesthesia with thiopental sodium (6 $\mathrm{mg} / \mathrm{kg}$, intravenously), the animals were killed by exsanguination, SDFT samples were removed, and each was divided into two portions. One portion was cut into pieces of approximately $10 \times 10 \times 5 \mathrm{~mm}$ and fixed in $4 \%(\mathrm{w} / \mathrm{w})$ paraformaldehyde in $0.1 \mathrm{M}$ sodium phosphate buffer, $\mathrm{pH}$ 7.4 , for $12 \mathrm{hr}$ at $4^{\circ} \mathrm{C}$ and then embedded in paraffin wax according to standard procedures. The other portion was cut into small pieces of $5 \times 5 \times 5 \mathrm{~mm}$, immediately frozen in liquid nitrogen, and stored at $-80^{\circ} \mathrm{C}$ until use. Additionally, testis samples were collected from two horses with normal tendons for in situ hybridization.

Reverse transcriptional-polymerase chain reaction ( $R T$ $P C R)$ and PCR-Southern blotting: Total RNA was isolated from normal, inflamed and scar-formed tendons using Trizol (Invitrogen, Carlsbad, CA, U.S.A.), an RNA isolation regent. For RT-PCR, complementary DNA (cDNA) was synthesized from total RNA samples using a SuperScript Preamplification System for first-strand cDNA synthesis (Invitrogen) according to the manufacturer's protocol. These cDNA samples were then subjected to PCR with specific primers for equine $T N F \alpha$. After denaturation, $T N F \alpha$ specific cDNA fragments were amplified with 2.5 U Taq polymerase by the hot-start procedure (TaKaRa Ex Taq; TAKARA, Shiga, Japan). Amplification was performed for 40 cycles in a thermal cycle reactor. Each cycle consisted of denaturation for $30 \mathrm{~s}$ at $94^{\circ} \mathrm{C}$, primer annealing for $30 \mathrm{~s}$ at $60^{\circ} \mathrm{C}$ and extension for $30 \mathrm{~s}$ at $72^{\circ} \mathrm{C}$ for 40 cycles. As an internal control for RNA extraction and cDNA synthesis, PCR amplification was also performed on all cDNA samples using primers specific for the constitutively expressed gene $\beta$-actin. Specific primer pairs for RT-PCR were designed from sequence of TNF $\alpha$ and $\beta$-actin in the GenBank database (accession numbers: AB035735 and AF035774, respectively). They were $T N F \alpha$ forward primer (AGCCCATGTTGTAGCAAACC) at 305-324 and reverse primer (GTTGGGCTGATTGATCTCAGC) at 686-666 of $\mathrm{AB} 035735$ and $\beta$-actin forward primer (GACCCAGATCATGTTTGAGACCT) at 357-379 and reverse primer (TGATGGAGTTGAAGGTAGTTTCGTG) at 847-823 of AF035774. The amplified products were electrophoresed in $1.5 \%(\mathrm{w} / \mathrm{v})$ agarose gels at $100 \mathrm{~V}$ for $30 \mathrm{~min}$ in TAE buffer
(40 mM Tris-acetate, $1 \mathrm{mM}$ EDTA, $\mathrm{pH}$ 8.0). The gels were stained with ethidium bromide and then photographed under ultra violet transillumination light. Amplification of the housekeeping gene $\beta$-actin was used as a positive control. Band intensities of TNF $\alpha$ transcript level were analyzed by densitometry using NIH image after normalized against that of the $\beta$-actin band.

PCR-Southern blot analysis was performed to detect the presence of DNA of TNFa. After electrophoresis, amplified TNF $\alpha$ DNA fragments were transferred to a polyvinylidene fluoride (PVDF) membrane (Millipore Corporation, Billerica, MA, U.S.A.). The membrane was incubated at $68^{\circ} \mathrm{C}$ for $1 \mathrm{hr}$ in prehybridization buffer containing $5 \times \mathrm{SSC}[150 \mathrm{mM} \mathrm{NaCl}, 15 \mathrm{mM}$ sodium citrate, $\mathrm{pH}$ $7.0,1.0 \%(\mathrm{w} / \mathrm{v})$ blocking reagent, $0.1 \%(\mathrm{w} / \mathrm{v})$ sarkosyl and $0.02 \%(\mathrm{w} / \mathrm{v}) \mathrm{SDS}]$. Hybridization was performed in a prehybridization mixture containing a digoxigenin-labeled oligonucleotide probe $(10 \mathrm{pmol} / \mathrm{m} l)$ at $55^{\circ} \mathrm{C}$ for $6 \mathrm{hr}$. The probe was the nucleotide residue 316-360 (probe 2) of horse TNF $\alpha$ cDNA as noted in the methods used for in situ hybridization. After hybridization, the membrane was washed twice for 5 min with $2 \times \mathrm{SSC}-0.1 \%(\mathrm{w} / \mathrm{v}) \mathrm{SDS}$ at room temperature and then washed twice with $0.2 \times \mathrm{SSC}$ $0.1 \%(\mathrm{w} / \mathrm{v}) \mathrm{SDS}$ for $5 \mathrm{~min}$ at $55^{\circ} \mathrm{C}$. Hybridized bands were revealed according to the method recommended by the supplier (Nonradioactive DNA detection kit; Boehringer Mannheim, Mannheim, Germany).

In situ hybridization: Two non-overlapping antisense oligonucleotides were used for in situ hybridization. They were complementary to nucleotides residues 194-238 (probe 1: AAGGC ATTCG GTAAC TGCTC TTCCC TCTGG GGGCC GATCA CCCCA) and 316-360 (probe 2: GCCCA CTCAG CCACT GGAGC TGCCC CTCGG CTTGG GGGTT TGCTA) of horse $T N F \alpha$ cDNA (GenBank accession No. AB035735). These oligonucleotides were labeled with ${ }^{35} \mathrm{~S}$-dATP using terminal deoxyribonucleotidyl transferase (Promega, Madison, WI, U.S.A.) at a specific activity of $0.5 \times 10^{9} \mathrm{dpm} / \mu \mathrm{g}$ DNA. Fresh frozen sections, each $10 \mu \mathrm{m}$ in thickness, were prepared and mounted on glass slides precoated with 3-amino propyltriethoxylane (ShinEtsu Chemical, Tokyo, Japan). Sections were fixed with $4 \%(\mathrm{v} / \mathrm{v})$ paraformaldehyde for $10 \mathrm{~min}$ and acetylated for $10 \mathrm{~min}$ with $0.25 \%(\mathrm{v} / \mathrm{v})$ acetic anhydride in $0.1 \mathrm{M}$ triethanolamine $\mathrm{HCl}, \mathrm{pH} 8.0$. The sections were prehybridized for $2 \mathrm{hr}$ in a buffer containing $50 \%(\mathrm{v} / \mathrm{v})$ formamide, $0.1 \mathrm{M}$ Tris- $\mathrm{HCl}(\mathrm{pH} 7.5), 4 \times \mathrm{SSC}(150 \mathrm{mM} \mathrm{NaCl}, 15$ $\mathrm{mM}$ sodium citrate), $0.02 \%(\mathrm{w} / \mathrm{v})$ Ficoll, $0.02 \%(\mathrm{w} / \mathrm{v})$ polyvinylpyrrolidone, $0.02 \%(\mathrm{w} / \mathrm{v})$ bovine serum albumin, 0.6 $\mathrm{M} \mathrm{NaCl}, 0.25 \%$ (w/v) SDS, $200 \mu \mathrm{g} / \mathrm{m} l$ tRNA, $1 \mathrm{mM}$ Ethylenediamine tetraacetic acid (EDTA) and $10 \%(\mathrm{w} / \mathrm{v})$ dextran sulfate. Hybridization was performed at $42^{\circ} \mathrm{C}$ for $10 \mathrm{hr}$ in hybridization buffer supplemented with $10,000 \mathrm{cpm} / \mu \mathrm{l}$ of ${ }^{35} \mathrm{~S}$-labeled oligonucleotide probes. The slides were washed at room temperature for $20 \mathrm{~min}$ in $2 \times \mathrm{SSC}$ containing $0.1 \%$ $(\mathrm{w} / \mathrm{v})$ sarkosyl and twice at $55^{\circ} \mathrm{C}$ for $40 \mathrm{~min}$ in $0.1 \times \mathrm{SSC}$ containing $0.1 \%(\mathrm{w} / \mathrm{v})$ sarkosyl. The sections were exposed to Hyperfilm- $\beta$ max (Amersham, Buckingnghamshire, UK) 
for two weeks.

Immunohistochemical analysis: Frozen sections of $10 \mu \mathrm{m}$ in thickness were cut and immunohistochemically stained by the avidin-biotin complex (ABC) method. Briefly, after blocking of endogenous peroxidase activity by methyl alcohol with $0.5 \% \mathrm{H}_{2} \mathrm{O}_{2}$ and blocking of non-specific binding with $10 \%$ goat or rabbit serum, the sections were incubated with each primary antibody for $18 \mathrm{hr}$ at $4^{\circ} \mathrm{C}$. For intracellular signaling assays, 4 primary antibodies were diluted with PBS as follows: mouse anti-equine TNF $\alpha$ monoclonal antibody $(1: 100$; self product, detail manuscripts concerning anti-TNF $\alpha$ antibody are in preparation), mouse anti-human TNF-R1 monoclonal antibody (1:100; Santa Cruz Biochemistry, Santa Cruz, CA, U.S.A.), rabbit anti-human TRAF2 polyclonal antibody (1:50; Santa Cruz) and rabbit antihuman caspase-3 polyclonal antibody [1:50; Cleaved Caspase-3 (Asp175) Antibody \#9661; Cell Signaling, Beverly, MA, U.S.A.]. The caspase-3 antibody used in this immunohistochemial assay detects only activated caspase3. The antigen-antibody reactions were visualized by biotin-labeled rabbit anti-mouse $\mathrm{IgG}, \mathrm{A}$ and $\mathrm{M}$ (Histofine; Nichirei, Tokyo, Japan) for $30 \mathrm{~min}$ at room temperature and reacted with peroxidase-streptavidin complex (Nichirei). An enzyme reaction was developed with a mixture of $0.04 \%$ $(\mathrm{w} / \mathrm{v})$ diaminobenzidine (DAB; Wako Chemical, Osaka, Japan) and $0.002 \% \mathrm{H}_{2} \mathrm{O}_{2}$ in $0.05 \mathrm{M}$ Tris- $\mathrm{HCl}$ buffer, $\mathrm{pH}$ 7.6. Sections were counterstained with methyl green, washed, dehydrated, mounted with Eukitt (O. Kindler, Freiburg, Germany), and then examined under a microscope. The specificity of the immunoreactions was tested by replacement of the primary antibodies with normal serum and PBS.

Western blot analysis: To detect TNF-R1, TRAF2 and caspase- 3 proteins in the normal, inflamed and scar-formed tendons, tendon tissues were lysed and each aliquot of 1.5 $\mu \mathrm{g} / \mu l$ protein from each tendon loaded $20 \mu l$ to $12.5-15 \%$ sodium dodecyl/polyacrylamide gel electrophoresis (SDSPAGE) before transfer to PVDF membranes (Millipore). Each blotted membrane was soaked with blocking buffer containing $3 \%(\mathrm{w} / \mathrm{v})$ skim milk in Tris-buffered saline (TBS; $20 \mathrm{mM}$ Tris and $500 \mathrm{mM} \mathrm{NaCl}, \mathrm{pH} 7.6$ ) with $0.2 \%$ (w/v) polyoxyethylene sorbitan monolaurate (Tween20; Kanto Chemical, Tokyo, Japan) and then incubated for $1 \mathrm{hr}$ with each primary antibody. The primary antibodies used were mouse anti-human TNF-R1 monoclonal antibody (1:1,000; Santa Cruz), rabbit anti-human TRAF2 polyclonal antibody (1:500; Santa Cruz) and rabbit anti-human caspase-3 polyclonal antibody (1:500; Caspase-3 Antibody \#9662; Cell Signaling), in 1\% (w/v) skim milk/TBS/ Tween 20. The caspase-3 antibody used in this study is able to detect both the full length (inactivated) and a large fragment of activated caspase-3. After reaction with primary antibodies, blotted membranes were developed with an ECL blotting system (Amersham Biosciences, Piscataway, NJ, U.S.A.) according to manufacturer's instructions. The density of the bands on the developed film was analyzed by using NIH image software. The values of each band's densitys in each SDFTs (normal, inflamed and scar-formed ten- dons) were divided by the value of normal tendon for the comparison of amounts of the protein.

\section{RESULTS}

$T N F \alpha$ mRNA expression in horse tendon tissues: $T N F \alpha$ mRNA signals were detected in all tendon tissues, but the levels were low in normal and scar-formed tissues. The results of semiquantitative analyses, RT-PCR and PCRSouthern blot analyses, showed that the mRNA level in inflamed tissue was 2.7-times higher than that in normal tissue (Fig. 1a and b), but only a trace reaction was observed in scar-formed tissue.

In situ hybridization analysis of TNF $\alpha$ in horse tendon tissues: The probe exhibited almost identical labeling patterns, whereas the sense probes did not show any specific hybridization signals. TNF $\alpha$ mRNA signals were only faintly detected in normal tendon tissues but were stronger
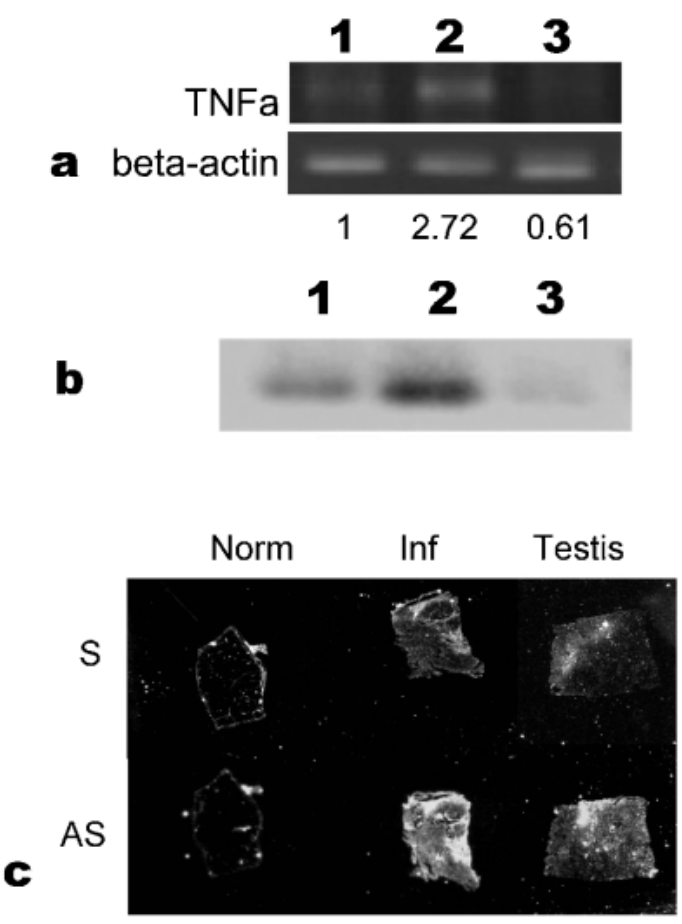

Fig. 1. TNF $\alpha$ mRNA expressions in normal, inflamed and scar formed SDFTs by RT-PCR (a) and PCR-Southern blot (b). TNF $\alpha$ mRNA levels in each tendons were normalized using $\beta$-actin mRNA levels, and the figures under RT-PCR analysis panel is the ratio of the normalized band's density (Fig. 1a). TNF $\alpha$ mRNA level in inflamed and scar-formed tendon tissues was about 2.7and 0.6-times stronger than that in normal tissue, respectively. Strong signals were observed in the inflamed SDFT by in situ hybridization methods (Fig. 1c). Lane 1 , normal tendon; lane 2, inflamed tendon; lane 3, scarformed tendon. $\mathrm{S}$, sense probe; $\mathrm{AS}$, antisense probe. Norm, normal tendon; Inf, inflamed tendon; Testis, positive control for detecting $T N F \alpha$ mRNA signals obtained from horses with normal tendon. 

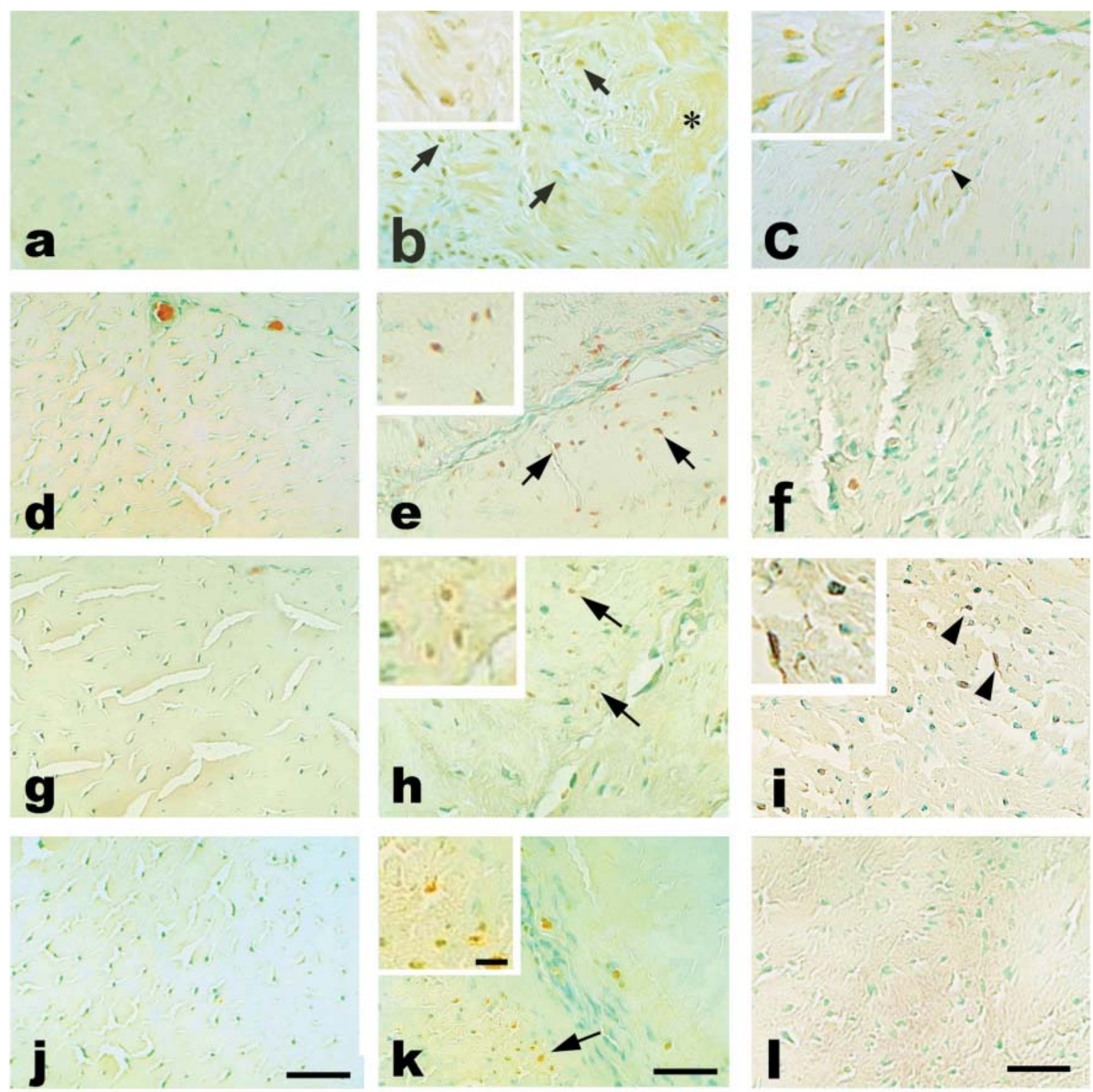

Fig. 2. Results of immunohistochemical examination for TNF $\alpha$ (a-c), TNF-R1 (d-f), TRAF2 (g-i) and activated caspase-3 (j-1) by the ABC method in normal (a, d, g, j), inflamed (b, e, h, k) and scar-formed SDFTs (c, f, i, l). Counter-staining with methyl green. Few immunopositive cells were detected in the normal SDFT (a, d, g, j), but numerous such cells (arrows) were present in the degenerated area shown (b, e, h, k). TNF $\alpha$ was also distributed in the extracellular area in the inflamed SDFT (b; asterisk). Most cells in the scar-formed SDFT were negative against TNF-R1 (f) and activated caspase-3 (l) antibodies, but some TNF $\alpha$ - and TRAF2 -positive cells were found in the scar-formed SDFT (c and i; arrowheads). Scale bars, $200 \mu \mathrm{m}$. Scale bar in inset, $50 \mu \mathrm{m}$.

in inflamed tendon tissues (Fig. 1c). Weak signals were localized in the periendotendinium area, but the most remarkable signals were localized in the degenerated tendon fascicle area.

Immunohistochemical observation: Immunohistochemical labeling revealed large numbers of TNF $\alpha$, TNF-R1, TRAF2 and activated caspase-3-positive cells in obviously degenerative areas of inflamed tissues (Fig. 2). Although small numbers of inflammatory cells such as neutrophilic leukocytes and macrophages were found in the inflamed area, immunopositive reaction was distributed in mainly spindle-shaped or oval-shaped cells, thought to be tendinocytes or tenoblasts. TNF $\alpha$ protein was also distributed in the extracellular area in the inflamed tendon. In contrast, most cells in the scar-formed tendons showed negative or only weak immunoreactions against TNF-R1, TRAF2 and activated caspase- 3 antibodies, while some TNF $\alpha$-immunopositive cells were detected in the scar-formed tendon tis- 


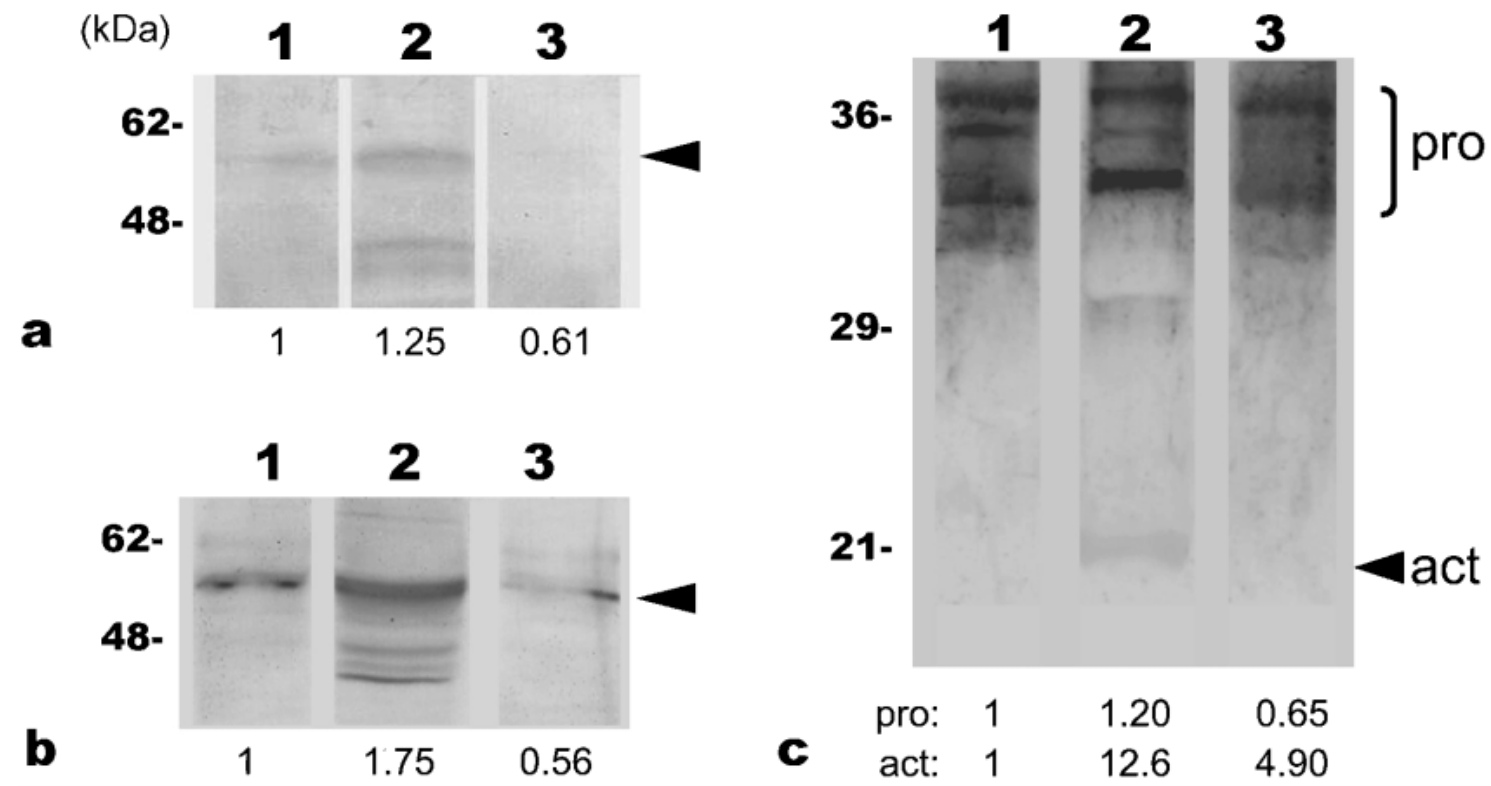

Fig. 3. Western blot analyses of TNF-R1, TRAF2 and caspase-3 in SDFTs (extracts of normal, inflamed and scar-formed tendons). TNF-R1 (a), TRAF2 (b) and caspase-3 (c) were detected in normal (lane 1), inflamed (lane 2) and scar-formed (lane 3) SDFTs. In the analysis of caspase- 3 , the bands at 32-35 kDa indicate procaspase-3 (pro; lanes 1-3), whereas the activated form of caspase- 3 (act) at $17 \mathrm{kDa}$ was detected only in inflamed tendons (lane 2). The figures under each membrane indicate the ratio of the band's density of normal, inflamed and scar-formed SDFTs.

sues. Even in the normal tendon, tendinocytes showed immunoreactions against TNF $\alpha$ and TRAF2 antibodies, but only a few cells showed immunoreactions against TNF-R1 and activated caspase- 3 antibodies.

No positive immunoreactions were found in any section in the negative controls.

Western blot analyses in tendon tissues: TNF-R1 was weakly detected in normal tendon tissue, but a significantly strong band appeared in inflamed tendon tissue. Scarformed tissue showed a very weak reaction (Fig. 3a). Although TRAF2 protein was difficult to detect in the scarformed tendon tissue, normal tendon tissue showed a relatively strong band as did inflamed tendon tissue (Fig. 3b). Procaspase-3 (32-35 kDa) was detected in all tendon tissues (Fig. 3c, lanes 1-3), whereas another new band of activated domain of caspase-3 (17 kDa) was detected in the inflamed tendon tissue (Fig. 3c, lane 2). Only the inflamed tissue samples yielded intense bands of activated caspase- 3 protein on the PDVF membrane indicating excessive apoptosis. The density ratio of TNF-R1, TRAF2, procaspase- 3 and activated caspase- 3 in normal tendon, inflamed tendon and scar-formed tendon tissues were 1:1.25:0.61, 1:1.75:0.56, $1: 1.20: 0.65$ and $1: 12.6: 4.90$, respectively.

\section{DISCUSSION}

In this study, we focused on four signaling factors, TNF $\alpha$, TNF-R1, TRAF2 and caspase-3, and investigated changes in the distribution and expression of these factors during healing of a tendon injury. TNF $\alpha$ modulates cell survival $[28,29]$ and apoptosis $[12,15,17,22,31]$ in many cell types through two receptors, TNF-R1 and TNF-R2. Both receptors, TNF-R1 and TNF-R2 [23, 25], mediate cell survival signals; TNF-R1 is predominant in mediating the TNF $\alpha$ effect on apoptosis [26]. At least one of these TNF-Rs is expressed by almost all cell types [25], and we have shown that TNF-Rs are distributed on tendinocytes in vitro [5]. Recently, Manabe and colleagues reported that two distinct signaling pathways, cell survival and apoptosis pathways, mediated by TNF-R1 exist in the swine ovarian follicle [9, $18,21]$. This is a physiological phenomenon (atretic follicle) observed in the process of development of oocytes; however, in this study, we demonstrated that two conflicting signaling pathways mediated by TNF-R1 also exist in tendons, especially in tendons in the pathological condition of tendonitis.

We found that the distribution of the four signaling factors differed depending on the tendon condition, normal, inflamed or scar-formed. In the normal tendon, large amounts of TRAF 2 protein were distributed in tendinocytes, but the expression level of TNF-R1 protein was low. These findings suggest that some pathways that stimulate the function of TRAF2 without mediating TNF-R1 exist in tendinocytes. It is well known that TRAF2 mediates signals not only through TNF-R1 but also through TNF-R2, which transmits only cell survival signals $[24,25]$. Actually, overexpression of TRAF2 causes activation of NF- $\kappa B$, whereas a dominant negative mutant of TRAF2 blocks TNF-R2- 
mediated NF- $\mathrm{kB}$ activation, suggesting a central role of TRAF2 in TNF-R2 signaling [23]. In our previous study, we have shown that TNF-R2 exists on equine tendinocytes in a normal condition, and we also confirmed production of TRAF2 and NF- $\mathrm{BB}$ [5]. These factors are deeply related to TNF-R2 pathways [18, 21, 24]. Therefore, the presence of a TNF-R2-TRAF2 pathway in normal tendinocytes is likely.

$T N F \alpha$ mRNA was found to be expressed most strongly in the inflamed tendon. The production of TNF-R1 protein, which was hardly detected in the normal tendon, also increased in the inflamed tendon, and the amounts of TRAF2 and procaspase- 3 proteins also increased. The finding of remarkable upregulation of TNF $\alpha$ and activated caspase-3 proteins supports the results of our previous study showing a large number of apoptotic cells in the inflamed tendon $[4,6]$. The increase in TRAF2 proteins, which is a signaling factor closely related to cell survival, in the inflamed tendon is also notable. A small number of inflammatory cells such as neutrophilic leukocytes and macrophages were found in the inflamed area, but tendinocytes accounted for most of the cells in the inflamed tendon [11]. These results suggested that two distinct intracellular signaling pathways, which lead to cell survival and apoptosis, were present and reinforced in tendinocytes mediated through TNF-R1.

The scar-formed tendons showed a wide range of structural alterations as well as cellular abnormalities. The streamed arrangement of collagen and homogenous distribution pattern of tendinocytes in normal tendons had changed into random collagen orientation and hypocellularity as well as clustering of round-shaped (tenoblast-like) cells in multifocal areas in the scar-formed tendons [11]. This cellular structural transformation might reflect changes in the properties of tendinocytes. In human dermal scar fibroblasts, TNF-R1-mediated apoptosis-associated genes were downregulated [19], and many transcriptional factors showed down-expression assessed by cDNA microarray [27]. Decreases in levels of TNF-R1, TRAF2 and caspase3 may indicate the turning down of intracellular signaling transmission and leading inactivation of cellular turnover.

In the present study, we found that two distinct intracellular signaling pathways of TNF $\alpha$, which lead to cell survival and apoptosis, might be present in tendinocytes mediated through TNF-R1. We also found that the expression and distribution patterns of these factors changed during tendon healing. A further study is needed to determine whether the signaling pathways for cell survival and apoptosis are present in the same cell or not. Our results reflect the dynamism of TNF $\alpha$ and also provide important clues for means to prevent the occurrence of tendonitis and progress of tendon degeneration.

ACKNOWLEDGEMENTS. The authors thank Dr. Toshihiko Iwanaga, Graduate School of Medicine, Hokkaido University, for his helpful technical advice. This study was partly supported by the Kuribayashi Scholarship Foundation, Japan.

\section{REFERENCES}

1. Beg, A. A. and Baltimore, D. 1996. An essential role for NF$\kappa \mathrm{B}$ in preventing TNF- $\alpha$-induced cell death. Science 274: 782 784.

2. Chinnaiyan, A. M., O'Rourke, K., Tewari, M. and Dixit, V. M. 1995. FADD, a novel death domain-containing protein, interacts with the death domain of Fas and initiates apoptosis. Cell 81: $505-512$.

3. Hallenbeck, J. M. 2002. The many faces of tumor necrosis factor in stroke. Nat. Med. 8: 1363-1368.

4. Hosaka, Y., Kirisawa, R., Yamamoto, E., Ueda, H., Iwai, H. and Takehana, K. 2002. Localization of cytokines in tendinocytes of the superficial digital flexor tendon in the horse. $J$. Vet. Med. Sci. 64: 945-947.

5. Hosaka, Y., Sakamoto, Y., Kirisawa, R., Watanabe, T., Ueda, H., Takehana, K. and Yamaguchi, M. 2004. Distribution of TNF receptors and TNF receptor-associated intracellular signaling factors on equine tendinocytes in vitro. Jpn. J. Vet. Res. 52: $135-144$.

6. Hosaka, Y., Teraoka, H., Yamamoto, E., Ueda, H. and Takehana, K. 2005. Mechanism of cell death in inflamed superficial digital flexor tendon in the horse. J. Comp. Pathol. 132: 51-58.

7. Hsu, H., Shu, H. B., Pan, M. G. and Goeddel, D. V. 1996. TRADD-TRAF2 and TRADD-FADD interactions define two distinct TNF receptor 1 signal transduction pathways. Cell 84: 299-308.

8. Hsu, H., Xiong, J. and Goeddel, D. V. 1995. The TNF receptor 1-associated protein TRADD signals cell death and NF- $\kappa B$ activation. Cell 81: 495-504.

9. Inoue, N., Manabe, N., Matsui, T., Maeda, A., Nakagawa, S., Wada, S. and Miyamoto, H. 2003. Roles of tumor necrosis factor-related apoptosis-inducing ligand signaling pathway in granulosa cell apoptosis during atresia in pig ovaries. $J$. Reprod. Dev. 49: 313-321.

10. Janicke, R. U., Sprengart, M. L., Wati, M. R. and Porter, A. G. 1998. Caspase-3 is required for DNA fragmentation and morphological changes associated with apoptosis. J. Biol. Chem. 273: 9357-9360.

11. Jozsa, L. G. and Kannus, P. 1997. pp. 76-81. In: Human Tendons: Anatomy, Physiology and Pathology. Human Kinetics, Champaign, Illinois

12. Klein, S. A., Dobmeyer, J. M., Dobmeyer, T. S., Falke, D., Kabelitz, D., Friese, K., Helm, E. B., Hoelzer, D. and RossolVoth, R. 1996. TNF- $\alpha$ mediated apoptosis of CD4 positive Tlymphocytes. A model of T-cell depletion in HIV infected individuals. Eur. J. Med. Res. 1: 249-258.

13. Le, J. and Vilcek, J. 1987. Tumor necrosis factor and interleukin 1: cytokines with multiple overlapping biological activities. Lab. Invest. 56: 234-248.

14. Lee, S. Y., Reichlin, A., Santana, A., Sokol, K. A., Nussenzweig, M. C. and Choi, Y. 1997. TRAF2 is essential for JNK but not NF- $\kappa$ B activation and regulates lymphocyte proliferation and survival. Immunity 7: 703-713.

15. Lewis, G. D., Aggarwal, B. B., Eessalu, T. E., Sugarman, B. J. and Shepard, H. M. 1987. Modulation of the growth of transformed cells by human tumor necrosis factor- $\alpha$ and interferon$\gamma$. Cancer Res. 47: 5382-5385.

16. Loetscher, H., Pan, Y. C., Lahm, H. W., Gentz, R., Brockhaus, M., Tabuchi, H. and Lesslauer, W. 1990. Molecular cloning and expression of the human $55 \mathrm{kd}$ tumor necrosis factor receptor. Cell 61: 351-359.

17. Madigan, M. C., Sadun, A. A., Rao, N. S., Dugel, P. U., Ten- 
hula, W. N. and Gill, P. S. 1996. Tumor necrosis factor- $\alpha$ $(\mathrm{TNF}-\alpha)$-induced optic neuropathy in rabbits. Neurol. Res. 18: 176-184.

18. Manabe, N., Goto, Y., Matsuda-Minehata, F., Inoue, N., Maeda, A., Sakamaki, K. and Miyano, T. 2004. Regulation mechanism of selective atresia in porcine follicles: regulation of granulosa cell apoptosis during atresia. J. Reprod. Dev. 50: 493-514.

19. Messadi, D. V., Le, A., Berg, S., Jewett, A., Wen, Z., Kelly, P. and Bertolami, C. N. 1999. Expression of apoptosis-associated genes by human dermal scar fibroblasts. Wound Repair Regen. 7: 511-517.

20. Nagata, S. 1997. Apoptosis by death factor. Cell 88: 355-365.

21. Nakayama, M., Manabe, N., Inoue, N., Matsui, T. and Miyamoto, H. 2003. Changes in the expression of tumor necrosis factor (TNF) $\alpha$, TNF $\alpha$ receptor (TNFR) 2, and TNFR-associated factor 2 in granulosa cells during atresia in pig ovaries. Biol. Reprod. 68: 530-535.

22. Prins, J. B., Niesler, C. U., Winterford, C. M., Bright, N. A., Siddle, K., O'Rahilly, S., Walker, N. I. and Cameron, D. P. 1997. Tumor necrosis factor- $\alpha$ induces apoptosis of human adipose cells. Diabetes 46: 1939-1944.

23. Rothe, M., Sarma, V., Dixit, V., M. and Goeddel, D. V. 1995. TRAF2-mediated activation of NF- $\kappa$ B by TNF receptor 2 and CD40. Science 269: 1424-1427.

24. Shu, H. B., Takeuchi, M. and Goeddel, D. V. 1996. The tumor necrosis factor receptor 2 signal transducers TRAF2 and cIAP1 are components of the tumor necrosis factor receptor 1 signaling complex. Proc. Natl. Acad. Sci. U.S.A. 93: 1397313978.
25. Smith, C. A., Farrah, T. and Goodwin, R. G. 1994. The TNF receptor superfamily of cellular and viral proteins: activation, costimulation, and death. Cell 76: 959-962.

26. Tartaglia, L. A., Ayres, T. M., Wong, G. H. and Goeddel, D. V. 1993. A novel domain within the $55 \mathrm{kd}$ TNF receptor signals cell death. Cell 74: 845-853.

27. Tsou, R., Cole, J. K., Nathens, A. B., Isik, F. F., Heimbach, D. M., Engrav, L. H. and Gibran, N. S. 2000. Analysis of hypertrophic and normal scar gene expression with cDNA microarrays. J. Burn Care Rehabil. 21: 541-550.

28. van Antwerp, D. J., Martin, S. J., Kafri, T., Green, D. R. and Verma, I. M. 1996. Suppression of TNF- $\alpha$-induced apoptosis by NF-кB. Science 274: 787-789.

29. Vilcek, J., Tsujimoto, M., Palombella, V. J., Kohase, M. and Le, J. 1987. Tumor necrosis factor: receptor binding and mitogenic action in fibroblasts. J. Cell Physiol.(Suppl.) 5: 57-61.

30. Wajant, H., Pfizenmaier, K. and Scheurich, P. 2003. Tumor necrosis factor signaling. Cell Death Differ. 10: 45-65.

31. Wang, C. Y., Mayo, M. W. and Baldwin, A. S. Jr. 1996. TNFand cancer therapy-induced apoptosis: potentiation by inhibition of NF-кB. Science 274: 784-787.

32. Wang, C. Y., Mayo, M. W., Korneluk, R. G., Goeddel, D. V.

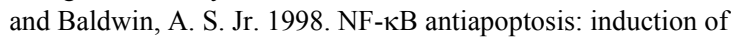
TRAF 1 and TRAF2 and c-IAP1 and c-IAP2 to suppress caspase-8 activation. Science 281: 1680-1683.

33. Yang, L., Lindholm, K., Konishi, Y., Li, R. and Shen, Y. 2002. Target depletion of distinct tumor necrosis factor receptor subtypes reveal hippocampal neuron death and survival through different signal transduction pathways. J. Neurosci. 22: 30253032 . 